\title{
Front Matter: Volume 9667
}

, "Front Matter: Volume 9667," Proc. SPIE 9667, International Workshop on Thin Films for Electronics, Electro-Optics, Energy, and Sensors, 966701 (20 November 2015); doi: 10.1117/12.2229403

SDIE Event: International Workshop on Thin Films for Electronics, Electro-Optics, Energy and Sensors, 2015, Suzhou, China 


\section{PROCEEDINGS OF SPIE}

\section{International Workshop on Thin Films for Electronics, Electro- Optics, Energy, and Sensors}

\section{Guru Subramanyam \\ Editor}

\section{4-6 July 2015 Suzhou, China}

Organized by

University of Dayton (United States)

University of Dayton China Institute (China)

Nanjing University of Science \& Technology (China)

Soochow University (China)

Published by

SPIE 
The papers in this volume were part of the technical conference cited on the cover and title page. Papers were selected and subject to review by the editors and conference program committee. Some conference presentations may not be available for publication. Additional papers and presentation recordings may be available online in the SPIE Digital Library at SPIEDigitallibrary.org.

The papers reflect the work and thoughts of the authors and are published herein as submitted. The publisher is not responsible for the validity of the information or for any outcomes resulting from reliance thereon.

Please use the following format to cite material from these proceedings:

Author(s), "Title of Paper," in International Workshop on Thin Films for Electronics, Electro-Optics, Energy, and Sensors, edited by Guru Subramanyam, Proceedings of SPIE Vol. 9667 (SPIE, Bellingham, WA, 2015) Six-digit Article CID Number.

ISSN: 0277-786X

ISSN: 1996-756X (electronic)

ISBN: 9781628418866

Published by

SPIE

P.O. Box 10, Bellingham, Washington 98227-0010 USA

Telephone +1 3606763290 (Pacific Time) · Fax +1 3606471445

SPIE.org

Copyright @ 2015 , Society of Photo-Optical Instrumentation Engineers.

Copying of material in this book for internal or personal use, or for the internal or personal use of specific clients, beyond the fair use provisions granted by the U.S. Copyright Law is authorized by SPIE subject to payment of copying fees. The Transactional Reporting Service base fee for this volume is $\$ 18.00$ per article (or portion thereof), which should be paid directly to the Copyright Clearance Center (CCC), 222 Rosewood Drive, Danvers, MA 01923. Payment may also be made electronically through CCC Online at copyright.com. Other copying for republication, resale, advertising or promotion, or any form of systematic or multiple reproduction of any material in this book is prohibited except with permission in writing from the publisher. The CCC fee code is 0277-786X/15/\$18.00.

Printed in the United States of America.

Publication of record for individual papers is online in the SPIE Digital Library.

\section{SPIE. DIGITAL}

Paper Numbering: Proceedings of SPIE follow an e-First publication model. A unique citation identifier (CID) number is assigned to each article at the time of publication. Utilization of CIDs allows articles to be fully citable as soon as they are published online, and connects the same identifier to all online and print versions of the publication. SPIE uses a six-digit CID article numbering system structured as follows:

- The first four digits correspond to the SPIE volume number.

- The last two digits indicate publication order within the volume using a Base 36 numbering system employing both numerals and letters. These two-number sets start with 00, 01, 02, 03, 04, 05, 06, 07 , $08,09,0 A, O B \ldots 0 Z$, followed by $10-1 Z, 20-2 Z$, etc. The CID Number appears on each page of the manuscript. 


\title{
Contents
}

\author{
V Authors \\ vii Conference Committee \\ ix Introduction
}

PRESENIED PAPERS

966702 Lightemission in silic on: from device physics to applications (Invited Paper) [9667-27]

966703 Optical tuning of electrical properties of PZT thin film deposited on STO [9667-30]

966704 Thin film banium strontium titanate femoelec tric varactors for mic rowave applications [9667-43]

966705 A resonant circ uit realization using a 3D inductor in combination with thin film varactor technology [9667-42]

966706 Nanostructured zinc oxide thin film for application to surface plasmon resonance based cholesterol biosensor [9667-29]

966707 Direct metal transfer printing on flexible substrate for fabricating optics functional devices [9667-23]

966708 Wavefront rec onstruction using smartphone based wavefront sensors [9667-12]

966709 Steerable beaming of photons with angular momentum using nano-emitter-coupled plasmonic structure (Invited Paper) [9667-14]

9667 OA Study on hydrophobic properties of two-dimensional grating on fluorine-containing azobenzene polymer film [9667-15]

9667 OB Method for the measurement of surface-relief grating's profile using initial phase of diffraction wave [9667-16]

9667 OC Both improvements of the light extraction efficiency and sc attered angle of GaN-LED using sub-mic ron Fresnel lens anay [9667-22]

9667 OD The transmission volume-phase holographic grating recorded on dichromated gelatin film used in Raman spectrometer [9667-26]

9667 OE Research on multi-source data integration and the extraction of three-dimensional displacement field based on G BSAR [9667-9]

9667 OF A comparison of atmospheric disturbance comection techniques in GBInSAR [9667-7]

9667 OG High order aspheric optical compensation system research [9667-20] 
9667 0T A fabrication approach of ionic polymer-metal composite for deformation sensors [9667-41]

Proc. of SPIE Vol. $9667966701-4$

Downloaded From: https://www.spiedigitallibrary.org/conference-proceedings-of-spie on 26 Apr 2023 Terms of Use: https://www.spiedigitallibrary.org/terms-of-use 


\title{
Authors
}

Numbers in the index correspond to the last two digits of the six-digit citation identifier (CID) article numbering system used in Proceedings of SPIE. The first four digits reflect the volume number. Base 36 numbering is employed for the last two digits and indicates the order of articles within the volume. Numbers start with 00, 01, 02, 03, 04, 05, 06, 07, 08, 09, 0A, 0B...0Z, followed by 10-1Z, 20-2Z, etc.

\author{
Cerny, Charles, 05 \\ Chen, Dong, OT \\ Chen, Linsen, 07, 0C \\ Dong, Ruili, OT \\ Feng, Fanrong, OB \\ Gao, Fei, OB \\ Gu, Xinyu, OC \\ Guo, Leping, OE \\ Gupta, Reema, 03 \\ Gupta, Vinay, 03, 06 \\ $\mathrm{He}$, Hong, OT \\ Jiang, Yingjie, 07 \\ Kaur, Gurpreet, 06 \\ Leedy, Kevin, 05 \\ Liu, Peng, OD \\ Mei, Qijing, OD \\ Ning, Ning, 02 \\ Ogudo, Kingsley A., 02 \\ Peng, Changsi, 07 \\ Polleux, Jean-Luc, 02 \\ Qiu, Shanming, OF \\ Qiu, Zhiwei, OF \\ Quach, Tony, 05 \\ Rui, Guanghao, 09 \\ Shen, Donghui, OG \\ Shen, Su, OC \\ Shi, Zhenwu, 07 \\ Shin, Eunsung, 04, 05 \\ Snyman, Lukas W., 02 \\ Spatz, Devin, 04 \\ Subramanyam, Guru, 04, 05 \\ Tan, Yonghong, OT \\ Tang, Minxue, OD \\ Tomar, Monika, 03, 06 \\ Wan, Wenqiang, OC \\ Wang, Jian, OA \\ Wang, Shu, 04, 05 \\ Wang, Weisong, 05 \\ Wang, Xueqin, OE, OF \\ Wu, Jianhong, OA, OB \\ Xie, Bin, OG \\ $\mathrm{Xu}$, Kaikai, 02 \\ $\mathrm{XU}$, Lixiong, $\mathrm{OA}$ \\ Yang, Zhenyu, 08 \\ $Y U$, Lingling, $O G$ \\ Yu, Qi, 02 \\ Yue, Hailing, 04 \\ Yue, Jianping, OE, OF \\ Yue, Shun, OE, OF
}

Zhan, Qiwen, 08, 09

Zhang, Congyue, $0 \mathrm{G}$

Zhang, Feng, 07

Zhou, Xiaohong, 07 
Proc. of SPIE Vol. $9667966701-6$

Downloaded From: https://www.spiedigitallibrary.org/conference-proceedings-of-spie on 26 Apr 2023 Terms of Use: https://www.spiedigitallibrary.org/terms-of-use 


\title{
Conference Committee
}

\author{
Conference Chair
}

Gunu Subramanyam, University of Dayton (United States)

Conference Co-chairs

Chinhua Wang, Soochow University (China)

Qiwen Zhan, University of Dayton (United States)

Chonglin Chen, The University of Texas at San Antonio (United States)

Conference Review Committee

Andrew M. Sarangan, University of Dayton (United States)

Andrew J. Steckl, University of C inc innati (United States)

Chonglin Chen, The University of Texas at San Antonio (United States)

K. C. J ames Raju, University of Hyderabad (India)

Eunsung Shin, University of Dayton Research Institute (United States) Imad H. Agha, University of Dayton (United Sta tes)

James G. Grote, Air Force Resea rch Laboratory (United States)

Joseph W. Haus, University of Dayton (United States)

Karolyn M. Hansen, University of Dayton (United States)

Nian X. Sun, Northeastem University (United Sta tes)

Partha P. Banerjee, University of Dayton (United Sta tes)

Paul Temence Murray, University of Dayton Research Institute

(United States)

Chungkun Song, Dong-A University (Korea, Republic of)

Chinhua Wang, So oc how University (China)

Wenyan Xu, Yanshan University (China)

Keqin Zhang, So oc how University (China)

Qiwen Zhan, University of Dayton (United States)

Ram Katiyar, University of Puerto Ric o (Puerto Rico)

Yu Wang, The Hong Kong Polytec hnic University (Hong Kong, China)

Wen Li, Michigan State University (United States)

Nelson Sepulveda, Mic higan State University (United Sta tes)

J itendra Kumar, University of Dayton (United States)

Sandwip Dey, Arizona Sta te University (United States)

Weisong Wang, University of Dayton (United States)

Wen Lu, Zhejiang Naboor Power Technology Inc. (China) 
Proc. of SPIE Vol. $9667966701-8$

Downloaded From: https://www.spiedigitallibrary.org/conference-proceedings-of-spie on 26 Apr 2023 Terms of Use: https://www.spiedigitallibrary.org/terms-of-use 


\section{Introduction}

The inaugural International Workshop on Thin-films for Electronics, Electro-Optics, Energy and Sensors (TFE3S) was successfully held from 4-6 July 2015 at the University of Dayton China Institute (Suzhou, China). This workshop was organized by the University of Dayton, the University of Dayton China Institute, Soochow University, and Nanjing University of Science and Technology. Prof. Guru Subramanyam from the Center of Excellence for Thin-film Research and Surface Engineering (CETRASE), University of Dayton served as program chair. The University of Dayton China Institute and the Dushu Lake Science \& Education Development Co. Ltd. provided local logistic services for the workshop. There were 83 participants, which included over 50 invited speakers and three plenary speakers, from the United States, India, Germany, Korea, Japan and China. The workshop set up 11 sessions related to

different areas of thin-films. Accepted papers are published by SPIE as a proceedings volume. 
Proc. of SPIE Vol. $9667966701-10$

Downloaded From: https://www.spiedigitallibrary.org/conference-proceedings-of-spie on 26 Apr 2023 Terms of Use: https://www.spiedigitallibrary.org/terms-of-use 